\title{
In silico Guided Drug Repurposing to Combat SARS-CoV-2 by Targeting Mpro, the key virus specific protease.
}

\author{
Ruchi Rani", Ankur Singh\#, Akshay Pareek, Shailly Tomar* \\ Department of Biotechnology, Indian Institute of Technology, Roorkee, Uttarakhand (247667), \\ India
}

$\left({ }^{\#}\right.$ Contributed equally to this article)

*Corresponding author Email: shailly.tomar@bt.iitr.ac.in, shaiprav@gmail.com

\begin{abstract}
The reemergence of SARS-CoV named, as SARS-CoV-2 has been highly infectious and able to infect a large population around the globe. The World Health Organization (WHO) has declared this SARS-CoV-2 associated Coronavirus Disease 2019 (COVID-19) as pandemic. SARS-CoV-2 genome is translated into polyproteins and has been processed by its protease enzymes. 3CLprotease is named as main protease $\left(\mathrm{M}^{\text {pro }}\right)$ enzyme which cleaves nsp4-nsp16. This crucial role of $\mathrm{M}^{\text {pro }}$ makes this enzyme a prime and promising antiviral target. The drug repurposing is a fast alternative method than the discovery of novel antiviral molecules. We have used high-throughput virtual screening approach to examine FDA approved LOPAC1280 library against $\mathrm{M}^{\text {pro }}$. Primary screening have identified few potential drug molecule for the target among which 10 molecules were studied further. Molecular docking of selected molecules was done to detailed study about their binding energy and binding modes. Positively, Etoposide, BMS_195614, KT185, Idarubicin and WIN_62577 were found interacting with substrate binding pocket of $\mathrm{M}^{\text {pro }}$ with higher binding energy. These molecules are being advanced by our group for in vitro and in vivo testing to study the efficacy of identified drugs. As per our understanding, these molecules have the potential to efficiently interrupt the viral life cycle and may reduce or eliminate the expeditious outspreading of SARS-CoV-2.
\end{abstract}

\section{Introduction}

Recent mysterious outbreak of infectious agent in Wuhan, China has drawn huge attention of all scientific community of world. WHO have named this pneumonia like illness as COVID19. Previously, epidemics of severe acute respiratory syndrome coronavirus (SARS-CoV) in Guangdong, China in 2003 and Middle East respiratory syndrome coronavirus (MERS-CoV) in 2013 have shown a high fatality rate. In both epidemics cases coronaviruses have shown cross-species transmission and infect humans as well as other vertebrates (Aleanizy et al., 2017; de Groot et al., 2013; Su et al., 2016; Wang et al., 2006; Zhong et al., 2003), In India, first coronavirus case confirmed on 30 January 2020 and till 23 march 2020 a total of 349 positive cases and 7 deaths have been confirmed in India (MOHFW, India). The occasional emergence of coronavirus has proved to be a substantial global threat to human lives.

According to International Committee on Taxonomy of Viruses (ICTV) coronavirus belongs to family Coronaviridae, subfamily Orthocoronavirineae and order Nidovirales which are 
enveloped positive-sense single-stranded RNA virus (Lefkowitz et al., 2018; Masters, 2006). On the basis of phylogenetic relationships and genome structures, Coronavirinae subfamily have been classified into four genera - Alphacoronavirus, Betacoronavirus, Gammacoronavirus and Deltacoronavirus. The former two genera generally infects mammals whereas other two genera infects birds. SARS-CoV and MERS-CoV belongs to the Betacoronavirus genus (Woo et al., 2010).

The genome size of SARS-CoV-2 is $\sim 30 \mathrm{~kb}$ with 12 open reading frames (ORFs). Genomic organization is in order 5'-replicase (rep)-spike (S)-envelope (E)-membrane (M)-nucleocapsid (N)-3' and short untranslated regions (Chan et al., 2020). The rep gene covers almost twothirds of the genome and encodes two overlapping polyproteins pp 1a and pplab using ORF1a and ORF1b. Papain-like protease and 3C-like protease cleaves the replicase polyprotein into 16 functional nonstructural proteins (nsp) that play a key role in transcription and replication of genome. (Fig. 1) (Cui et al., 2019; Song et al., 2019; Woo et al., 2010). Role of different non-structural proteins is as below (Table 1)

Downstream to rep gene sequence encodes four major structural proteins S, E, M and N which functions in formation of new virus progeny and their release (Rota et al., 2003). The S-protein are anchored protein over the envelope and interacts with host receptor by specific receptorbinding domain (RBD) (Wan et al., 2020) while E and M proteins are transmembrane proteins. The $\mathrm{N}$ binds with RNA at multiple sites and forms a helical nucleocapsid structure (Chang et al., 2014).

The $3 \mathrm{C}$-like protease is also referred as $\mathrm{M}^{\text {pro }}$ or $3 \mathrm{CL}^{\text {pro }}$ as it functions as main protease enzyme. It cleaves at different sites in downstream polyproteins and forms individual proteins (Xia and Kang, 2011). It is a 34-kDa protein, which have self-proteolytic activity to form a mature protease enzyme and function further (Yang et al., 2003). The monomer structure of $\mathrm{M}^{\text {pro }}$ have catalytic dyad of Cys-His at its active site whereas serine proteases have catalytic triad of SerHis-Asp (Anand et al., 2002). The proteolysis activity of 3CL protease have shown Gln as most favorable residue at its P1 position (Chuck et al., 2010). Its mature structure consists of $\mathrm{N}$ terminal domain I and domain II with chymotrypsin-like folds and a unique C-terminal domain III (Yang et al., 2003; Zhang et al., 2010).

Two monomers of $\mathrm{M}^{\text {pro }}$ forms its active structure as a homodimer by interaction between $\mathrm{C}$ terminal domains (Zhong et al., 2009). Among the two monomer units only one is in correct confirmation and catalysis induced upon the dimerization of protein (Chen et al., 2006). 1-7 residues of $\mathrm{N}$-terminal are termed as $\mathrm{N}$-finger, which is accommodated between two monomer units (Yang et al., 2003). This $\mathrm{N}$-finger is critical of dimerization of $\mathrm{M}^{\text {pro }}$ as well as formation of active dimeric form (Zhong et al., 2008). Further, a super active octamer form of $\mathrm{M}^{\text {pro }}$ has also been crystallized and studied which is highly active at low protein concentration (Zhang et al., 2010).

The substrate-binding pocket of $\mathrm{M}^{\text {pro }}$ have been specified by residues $41,140,142-145,161$, 163, 166 and 172 (Chen et al., 2006). His41 and Cys145 residues have been considered as prime residues for catalytic activity and remain conserved among Coronaviridae family 
members (Fig. 2). H41A and C145A mutations completely abolishes protease activity (Huang et al., 2004). At present no efficacious therapy or vaccine is available against SARS-CoV-2. 3CL protease have major role in viral life cycle, which makes it a prime target to discover antivirals against SARS-CoV-2. In this study, we have targeted substrate-binding site of $\mathbf{M}^{\text {pro }}$ and repurposed few well-known FDA approved drugs against SARS-CoV-2 $\mathrm{M}^{\text {pro }}$.

\section{Materials and Methods}

\section{Virtual Screening:}

To identify new potential antivirals against main protease $\left(\mathrm{M}^{\mathrm{pro}}\right)$ of SARS-CoV-2 (PDB ID: 6LU7), we have performed virtual screening of pharmacologically active compounds using PyRx 0.8. All the drug-like molecules were retrieved from LOPAC ${ }^{1280}$ drug library (Library of Pharmacologically Active Compounds, Sigma-Aldrich,St. Louis, MO) in SDF format. 1280 compounds were considered for high-throughput virtual screening. Energy minimization and conversion of all molecules into Autodock ligands (.pdbqt) format was done in PyRx 0.8. All the selected molecules were further undergone for screening against the probable binding sites of SARS-CoV-2 M ${ }^{\text {pro }}$ protein using PyRx 0.8 accompanied by AutoDock Vina. The grid centre points were set at $\mathrm{X}=-24.9165, \mathrm{Y}=12.3378, \mathrm{Z}=57.4364$ and box dimensions were set as $48.30 \AA \times 69.97 \AA \times 60.87 \AA$ with exhaustiveness 8. Top 10 molecules including Etoposide, BMS_195614, KT185, Idarubicin, GSK 121015A, WIN_62577, Eptifibatide_acetate, KT203, SB_202190 and GR_127935 were showing good binding efficacy and were selected for further analysis.

\section{Molecular Docking:}

Molecular docking of top 5 selected screened compounds were carried out using AutoDock 4.2.6. In docking procedure, all the water molecules were removed, non-polar hydrogens and Kollman charge (4.0) were added into the protein structure (PDB ID: 6LU7) using AutoDock MGL Tools 1.5.6. The protein was then saved in .pdbqt file format. The .pdbqt file format of top five hits ligands were retrieved from PyRx directory. The atomic potential grid map was calculated by AutoGrid 4 with a spacing of $0.316 \AA$ and grid box dimensions were selected as $(110 \AA \times 126 \AA \times 126 \AA)$. The centre point co-ordinates set was $\mathrm{X}=-26.529, \mathrm{Y}=12.599$ and $\mathrm{Z}=58.965$. Lamarckian Genetic Algorithm (GA) in combination of grid based energy evaluation method was used for docking. The number of total GA runs was increased 50 with maximum number of evaluations $(250,000,000)$. Other docking parameters were set as default.

\section{Results}

\section{Analysis of $\mathbf{M}^{\text {pro }}$ protease cleavage sites:}

Comparative analysis of different Coronavirinae family members $\mathrm{M}^{\text {pro }}$ cleavage site residues using Multalin webserver (Fig. 3). Sequence of SARS CoV-2, SARS-CoV and MERS-CoV were retrieved from NCBI. Multiple sequence alignment showed that most of the residues are conserved among them as shown in Fig.2. We selected these peptides residues as substrate for the protein. Further these peptide sequence were designed using PyMOL and then docked against protease. Docking result suggest that the binding affinity of these peptide are lower than the selected screened compounds as shown in Table 2. 


\section{Virtual screening:}

Potential antiviral compounds were extracted from LOPAC ${ }^{1280}$ drug library in SDF format. 1280 compounds were considered for high throughput virtual screening with main protease $\left(\mathrm{M}^{\text {pro }}\right)$ of SARS-CoV-2 (PDB ID: 6LU7). Each ligand showed 9 different poses while screening through PyRx. Top 10 Molecules were selected by virtual screening on the basis of their binding affinity. For analysis, the molecules having highest binding energy were considered as top hits compounds. We selected top 10 compounds based on their 3 binding energies that came in a range of -10.00 to $-8.2 \mathrm{kcal} / \mathrm{mol}$.

These selected screened molecules employed for docking with the $\mathrm{M}^{\text {pro }}$ to discover the potential inhibitor as shown in Fig. 4. Different length of peptide were also used as a substrate for comparison of the binding energy with the screened molecules. Pep1 is shown in Fig. 5.

\section{Molecular docking:}

Molecular docking of top 5 selected screened compounds were carried out using AutoDock 4.2.6. All the selected potential molecules fulfilling the five criteria of Lipinski rule. After the completion of docking, we found the binding energies of Etoposide, BMS_195614, KT185, Idarubicin, and WIN_62577 as $(-10.23 \mathrm{kcal} / \mathrm{mol}),(-10.03 \mathrm{kcal} / \mathrm{mol}),(-9.5 \mathrm{kcal} / \mathrm{mol}),(-9.06$ $\mathrm{kcal} / \mathrm{mol})$, and $(-8.95 \mathrm{kcal} / \mathrm{mol})$ and in silico inhibition constant $(\mathrm{ki})$ were obtained as 31.86 $\mathrm{nM}, 44.5 \mathrm{nM}, 106.5 \mathrm{nM}, 229.43 \mathrm{nM}, 273.66 \mathrm{nM}$. Molecular docking binding affinities of top 10 compounds are shown in Table 3 whereas molecular docking binding affinities, in-silico inhibition constant and interactions analysis of top five molecules are shown in Table 4. The analysis were performed by using PyMOL software (Fig. 4, 5, 6 \& 7) and LIGPLOT ${ }^{+}$(Fig. 8 ) to further understand the interaction between the protein and the ligand molecules.

Etoposide possessed maximum numbers of hydrogen bonds involving Leu141, Gly143, Ser144, His 163, Glu166 along with hydrophobic interaction His41, Phe140, Asn142, Cys145, His164, Met165, Leu167, Pro168, Asp187, Arg188, Gln189, Thr190 that displaying its affinity towards catalytic dyad (Fig. 6, 7, \& 8). Ligand BMS_195614 interacted through hydrophobic residues only. Ligand KT185 interacted with Arg188 through hydrogen bond while other through hydrophobic bonds that include His41,Cys145, His164, Met165, Glu166, Leu167, Pro168, Gly170, Asp187, Gln189, Thr190 (Fig. 6, 7, \& 8). Docked conformation of Idarubicin $(-9.06 \mathrm{kcal} / \mathrm{mol})$ and WIN_62577 $(-8.95 \mathrm{kcal} / \mathrm{mol})$ also displayed affinities towards the interacting residues by hydrogen and hydrophobic bonds.

Key interacting residues that play a significant role in all ligands along with other residues are His41, Phe140, Leu141, Asn142, Gly143, Cys145, His163, His164, Met165, Glu166, Leu167, Pro168, Asp187, Arg188, Gln189 and Thr190. The interaction clearly point out that these 5 screened drug molecules could potentially inhibit virus by inhibiting the main protease of SARS-CoV-2 by binding to the catalytic dyad of the protease which is responsible for its activity.

Further, different length of the peptide was also docked with the protease from which almost all peptide showed the docked score between $-7.5 \mathrm{kcal} / \mathrm{mol}$ to $-6.1 \mathrm{kcal} / \mathrm{mol}$ (Table 2). These 
docking result demonstrated that the selected screened drug molecules showed better docking and binding affinity profiles. Thus, these drug molecules may be selected as possible protease inhibitors against SARS-CoV-2.

\section{Discussion}

$\mathrm{M}^{\text {pro }}$ (also termed as 3CLprotease) is the major proteolytic enzyme of SARS-CoV-2. As it cleaves nsp4-nsp16, this makes it a prime target for antiviral studies. Understanding of the proteolytic cleavage sites and their interaction properties with inhibitor molecules can pave new pathway in the direction of antiviral therapy development and combat against this pandemic. Till date COVID-19 have affected more than hundred countries of the world and there is no effective drug is available against it. So, to avoid the prolonged process of new drug molecules identification drug repurposing would prove to be of great benefit against SARS-

CoV-2.

Non-structural polyprotein processing has been an important step in viral life-cycle which has mediated by $\mathrm{M}^{\text {pro }}$. It interacts with substrate peptide chain by catalytic dyad (His41 and Cys145) present in substrate binding pocket (Chen et al., 2006). Structure based drug repurposing of FDA approved drugs is a rapid method to identify inhibitor molecules which can block the binding pocket of $\mathrm{M}^{\text {pro }}$. We have successfully screened FDA approved LOPAC ${ }^{1280}$ drug library against the the most probable binding site of $\mathrm{M}^{\text {pro }}$ that includes the interecting sites i.e; His41, Cys145, Phe140, Asn142, Gly143, Ser144, Tyr161, His163, Glu166, His172. The best top ten drugs compounds gives the binding energy in the range of -10.23 $\mathrm{kcal} / \mathrm{mol}$ to $-8.2 \mathrm{kcal} / \mathrm{mol}$.

After the drug library screening, molecular docking studies enabled us to understand binding mode and crucial molecular interactions for potential drug molecules and $\mathbf{M}^{\text {pro }}$ substrate binding pocket. Intriguingly, all identified drug molecules are able to interact with His41 residue, which is key site for catalytic activity. The identified molecules and their roles have been listed in Table 5.

Our previous identification of KT185, KT203, BMS_195614, GSK1210151A, Eptifibatide acetate and GR127935 hydrochloride hydrate drug molecules have shown to inhibit the spikeACE2 interaction at virus entry step (Choudhary et al., 2020). So these molecules can be better antiviral candidates because of their inhibitory action at virus-host cell receptor interaction as well as post-translation step of non-structural proteins.

\section{Acknowledgement}

RR, AS and AP thanks University Grants Commission, Ministry of Human Resource Development and Council of Scientific \& Industrial Research, Government of India for financial support. Authors thank to Macromolecular Crystallographic Facility (MCU) at Indian Institute of Technology Roorkee (IIT Roorkee).

\section{References}

1. Adedeji, A.O., Marchand, B., Velthuis, A.J.W. te, Snijder, E.J., Weiss, S., Eoff, R.L., Singh, K., Sarafianos, S.G., 2012. Mechanism of Nucleic Acid Unwinding by SARS-CoV Helicase. PLOS ONE 7, e36521. https://doi.org/10.1371/journal.pone.0036521 
2. Ahn, D.-G., Choi, J.-K., Taylor, D.R., Oh, J.-W., 2012. Biochemical characterization of a recombinant SARS coronavirus nsp12 RNA-dependent RNA polymerase capable of copying viral RNA templates. Arch Virol 157, 2095-2104. https://doi.org/10.1007/s00705-012-1404-X

3. Aleanizy, F.S., Mohmed, N., Alqahtani, F.Y., El Hadi Mohamed, R.A., 2017. Outbreak of Middle East respiratory syndrome coronavirus in Saudi Arabia: a retrospective study. BMC Infect Dis 17. https://doi.org/10.1186/s12879-016-2137-3

4. Anand, K., Palm, G.J., Mesters, J.R., Siddell, S.G., Ziebuhr, J., Hilgenfeld, R., 2002. Structure of coronavirus main proteinase reveals combination of a chymotrypsin fold with an extra alphahelical domain. EMBO J. 21, 3213-3224. https://doi.org/10.1093/emboj/cdf327

5. Angelini, M.M., Akhlaghpour, M., Neuman, B.W., Buchmeier, M.J., 2013. Severe Acute Respiratory Syndrome Coronavirus Nonstructural Proteins 3, 4, and 6 Induce Double-Membrane Vesicles. mBio 4. https://doi.org/10.1128/mBio.00524-13

6. Beachboard, D.C., Anderson-Daniels, J.M., Denison, M.R., 2015. Mutations across Murine Hepatitis Virus nsp4 Alter Virus Fitness and Membrane Modifications. Journal of Virology 89, 2080-2089. https://doi.org/10.1128/JVI.02776-14

7. Bhardwaj, K., Guarino, L., Kao, C.C., 2004. The Severe Acute Respiratory Syndrome Coronavirus Nsp15 Protein Is an Endoribonuclease That Prefers Manganese as a Cofactor. Journal of Virology 78, 12218-12224. https://doi.org/10.1128/JVI.78.22.12218-12224.2004

8. Börgeling, Y., Schmolke, M., Viemann, D., Nordhoff, C., Roth, J., Ludwig, S., 2014. Inhibition of p38 Mitogen-activated Protein Kinase Impairs Influenza Virus-induced Primary and Secondary Host Gene Responses and Protects Mice from Lethal H5N1 Infection. J Biol Chem 289, 13-27. https://doi.org/10.1074/jbc.M113.469239

9. Bost, K.L., 2004. Tachykinin-modulated anti-viral responses. Front. Biosci. 9, 1994-1998. https://doi.org/10.2741/1376

10. Bottemanne, P., Paquot, A., Ameraoui, H., Alhouayek, M., Muccioli, G.G., 2019. The $\alpha / \beta-$ hydrolase domain 6 inhibitor WWL70 decreases endotoxin-induced lung inflammation in mice, potential contribution of 2-arachidonoylglycerol, and lysoglycerophospholipids. FASEB J. 33, 7635-7646. https://doi.org/10.1096/fj.201802259R

11. Bouvet, M., Imbert, I., Subissi, L., Gluais, L., Canard, B., Decroly, E., 2012. RNA 3'-end mismatch excision by the severe acute respiratory syndrome coronavirus nonstructural protein nsp10/nsp14 exoribonuclease complex. PNAS 109, 9372-9377. https://doi.org/10.1073/pnas.1201130109

12. Bouvet, M., Lugari, A., Posthuma, C.C., Zevenhoven, J.C., Bernard, S., Betzi, S., Imbert, I., Canard, B., Guillemot, J.-C., Lécine, P., Pfefferle, S., Drosten, C., Snijder, E.J., Decroly, E., Morelli, X., 2014. Coronavirus Nsp10, a critical co-factor for activation of multiple replicative enzymes. J. Biol. Chem. 289, 25783-25796. https://doi.org/10.1074/jbc.M114.577353

13. Chaidos, A., Caputo, V., Gouvedenou, K., Liu, B., Marigo, I., Chaudhry, M.S., Rotolo, A., Tough, D.F., Smithers, N.N., Bassil, A.K., Chapman, T.D., Harker, N.R., Barbash, O., Tummino, P., AlMahdi, N., Haynes, A.C., Cutler, L., Le, B., Rahemtulla, A., Roberts, I., Kleijnen, M., Witherington, J.J., Parr, N.J., Prinjha, R.K., Karadimitris, A., 2014. Potent antimyeloma activity of the novel bromodomain inhibitors I-BET151 and I-BET762. Blood 123, 697-705. https://doi.org/10.1182/blood-2013-01-478420 
14. Chang, C., Hou, M.-H., Chang, C.-F., Hsiao, C.-D., Huang, T., 2014. The SARS coronavirus nucleocapsid protein - Forms and functions. Antiviral Research 103, 39-50. https://doi.org/10.1016/j.antiviral.2013.12.009

15. Chen, H., Wei, P., Huang, C., Tan, L., Liu, Y., Lai, L., 2006. Only One Protomer Is Active in the Dimer of SARS 3C-like Proteinase. J. Biol. Chem. 281, 13894-13898. https://doi.org/10.1074/jbc.M510745200

16. Chen, Y., Su, C., Ke, M., Jin, X., Xu, L., Zhang, Z., Wu, A., Sun, Y., Yang, Z., Tien, P., Ahola, T., Liang, Y., Liu, X., Guo, D., 2011. Biochemical and Structural Insights into the Mechanisms of SARS Coronavirus RNA Ribose 2'-O-Methylation by nsp16/nsp10 Protein Complex. PLOS Pathogens 7, e1002294. https://doi.org/10.1371/journal.ppat.1002294

17. Cheng, H., Lear-Rooney, C.M., Johansen, L., Varhegyi, E., Chen, Z.W., Olinger, G.G., Rong, L., 2015. Inhibition of Ebola and Marburg Virus Entry by G Protein-Coupled Receptor Antagonists. J. Virol. 89, 9932-9938. https://doi.org/10.1128/JVI.01337-15

18. Choudhary, S., Malik, Y.S., Tomar, S., 2020. Identification of SARS-CoV-2 Cell Entry Inhibitors by Drug Repurposing Using in Silico Structure-Based Virtual Screening Approach (preprint). https://doi.org/10.26434/chemrxiv.12005988.v1

19. Chuck, C.-P., Chong, L.-T., Chen, C., Chow, H.-F., Wan, D.C.-C., Wong, K.-B., 2010. Profiling of Substrate Specificity of SARS-CoV 3CLpro. PLOS ONE 5, e13197. https://doi.org/10.1371/journal.pone.0013197

20. Cornillez-Ty, C.T., Liao, L., Yates, J.R., Kuhn, P., Buchmeier, M.J., 2009. Severe Acute Respiratory Syndrome Coronavirus Nonstructural Protein 2 Interacts with a Host Protein Complex Involved in Mitochondrial Biogenesis and Intracellular Signaling. Journal of Virology 83, 1031410318. https://doi.org/10.1128/JVI.00842-09

21. Cottam, E.M., Whelband, M.C., Wileman, T., 2014. Coronavirus NSP6 restricts autophagosome expansion. Autophagy 10, 1426-1441. https://doi.org/10.4161/auto.29309

22. Cui, J., Li, F., Shi, Z.-L., 2019. Origin and evolution of pathogenic coronaviruses. Nature Reviews Microbiology 17, 181-192. https://doi.org/10.1038/s41579-018-0118-9

23. de Groot, R.J., Baker, S.C., Baric, R.S., Brown, C.S., Drosten, C., Enjuanes, L., Fouchier, R.A.M., Galiano, M., Gorbalenya, A.E., Memish, Z.A., Perlman, S., Poon, L.L.M., Snijder, E.J., Stephens, G.M., Woo, P.C.Y., Zaki, A.M., Zambon, M., Ziebuhr, J., 2013. Middle East Respiratory Syndrome Coronavirus (MERS-CoV): Announcement of the Coronavirus Study Group. J Virol 87, 7790-7792. https://doi.org/10.1128/JVI.01244-13

24. Decroly, E., Debarnot, C., Ferron, F., Bouvet, M., Coutard, B., Imbert, I., Gluais, L., Papageorgiou, N., Sharff, A., Bricogne, G., Ortiz-Lombardia, M., Lescar, J., Canard, B., 2011. Crystal Structure and Functional Analysis of the SARS-Coronavirus RNA Cap 2'-O-Methyltransferase nsp10/nsp16 Complex. PLoS Pathog 7. https://doi.org/10.1371/journal.ppat.1002059

25. Deng, X., Hackbart, M., Mettelman, R.C., O’Brien, A., Mielech, A.M., Yi, G., Kao, C.C., Baker, S.C., 2017. Coronavirus nonstructural protein 15 mediates evasion of dsRNA sensors and limits apoptosis in macrophages. PNAS 114, E4251-E4260. https://doi.org/10.1073/pnas.1618310114

26. Egloff, M.-P., Ferron, F., Campanacci, V., Longhi, S., Rancurel, C., Dutartre, H., Snijder, E.J., Gorbalenya, A.E., Cambillau, C., Canard, B., 2004. The severe acute respiratory syndromecoronavirus replicative protein nsp9 is a single-stranded RNA-binding subunit unique in the RNA virus world. PNAS 101, 3792-3796. https://doi.org/10.1073/pnas.0307877101 
27. Graham, R.L., Sims, A.C., Baric, R.S., Denison, M.R., 2006. The nsp2 proteins of mouse hepatitis virus and SARS coronavirus are dispensable for viral replication. Adv. Exp. Med. Biol. 581, 6772. https://doi.org/10.1007/978-0-387-33012-9_10

28. Hao, W., Wojdyla, J.A., Zhao, R., Han, R., Das, R., Zlatev, I., Manoharan, M., Wang, M., Cui, S., 2017. Crystal structure of Middle East respiratory syndrome coronavirus helicase. PLOS Pathogens 13, e1006474. https://doi.org/10.1371/journal.ppat.1006474

29. Higgs, M.R., Lerat, H., Pawlotsky, J.-M., 2013. Hepatitis $C$ virus-induced activation of $\beta$-catenin promotes c-Myc expression and a cascade of pro-carcinogenetic events. Oncogene 32, 4683-4693. https://doi.org/10.1038/onc.2012.484

30. Hsu, K.-L., Tsuboi, K., Chang, J.W., Whitby, L.R., Speers, A.E., Pugh, H., Cravatt, B.F., 2013. Discovery and optimization of piperidyl-1,2,3-triazole ureas as potent, selective, and in vivo-active inhibitors of $\alpha / \beta$-hydrolase domain containing 6 (ABHD6). J. Med. Chem. 56, 8270-8279. https://doi.org/10.1021/jm400899c

31. Huang, C., Lokugamage, K.G., Rozovics, J.M., Narayanan, K., Semler, B.L., Makino, S., 2011. SARS Coronavirus nsp1 Protein Induces Template-Dependent Endonucleolytic Cleavage of mRNAs: Viral mRNAs Are Resistant to nsp1-Induced RNA Cleavage. PLOS Pathogens 7, e1002433. https://doi.org/10.1371/journal.ppat.1002433

32. Huang, C., Wei, P., Fan, K., Liu, Y., Lai, L., 2004. 3C-like Proteinase from SARS Coronavirus Catalyzes Substrate Hydrolysis by a General Base Mechanism. Biochemistry 43, 4568-4574. https://doi.org/10.1021/bi036022q

33. Johnson, J.C., Martinez, O., Honko, A.N., Hensley, L.E., Olinger, G.G., Basler, C.F., 2014. Pyridinyl imidazole inhibitors of p38 MAP kinase impair viral entry and reduce cytokine induction by Zaire ebolavirus in human dendritic cells. Antiviral Res 107, 102-109. https://doi.org/10.1016/j.antiviral.2014.04.014

34. Kirchdoerfer, R.N., Ward, A.B., 2019. Structure of the SARS-CoV nsp12 polymerase bound to nsp7 and nsp8 co-factors. Nature Communications 10, 1-9. https://doi.org/10.1038/s41467-01910280-3

35. Kumar, P., Gunalan, V., Liu, B., Chow, V.T.K., Druce, J., Birch, C., Catton, M., Fielding, B.C., Tan, Y.-J., Lal, S.K., 2007. The nonstructural protein 8 (nsp8) of the SARS coronavirus interacts with its ORF6 accessory protein. Virology 366, 293-303. https://doi.org/10.1016/j.virol.2007.04.029

36. Lê, V.B., Schneider, J.G., Boergeling, Y., Berri, F., Ducatez, M., Guerin, J.-L., Adrian, I., Errazuriz-Cerda, E., Frasquilho, S., Antunes, L., Lina, B., Bordet, J.-C., Jandrot-Perrus, M., Ludwig, S., Riteau, B., 2015. Platelet Activation and Aggregation Promote Lung Inflammation and Influenza Virus Pathogenesis. Am J Respir Crit Care Med 191, 804-819. https://doi.org/10.1164/rccm.201406-1031OC

37. Lefkowitz, E.J., Dempsey, D.M., Hendrickson, R.C., Orton, R.J., Siddell, S.G., Smith, D.B., 2018. Virus taxonomy: the database of the International Committee on Taxonomy of Viruses (ICTV). Nucleic Acids Res. 46, D708-D717. https://doi.org/10.1093/nar/gkx932

38. Lei, J., Kusov, Y., Hilgenfeld, R., 2018. Nsp3 of coronaviruses: Structures and functions of a large $\begin{array}{llll}\text { multi-domain } & \text { protein. } & \text { Antiviral }\end{array}$ https://doi.org/10.1016/j.antiviral.2017.11.001 
39. Mainou, B.A., Ashbrook, A.W., Smith, E.C., Dorset, D.C., Denison, M.R., Dermody, T.S., 2015. Serotonin Receptor Agonist 5-Nonyloxytryptamine Alters the Kinetics of Reovirus Cell Entry. J. Virol. 89, 8701-8712. https://doi.org/10.1128/JVI.00739-15

40. Masters, P.S., 2006. The Molecular Biology of Coronaviruses, in: Advances in Virus Research. Academic Press, pp. 193-292. https://doi.org/10.1016/S0065-3527(06)66005-3

41. Minskaia, E., Hertzig, T., Gorbalenya, A.E., Campanacci, V., Cambillau, C., Canard, B., Ziebuhr, J., 2006. Discovery of an RNA virus 3' $->5$ ' exoribonuclease that is critically involved in coronavirus RNA synthesis. Proc. Natl. Acad. Sci. U.S.A. 103, 5108-5113. https://doi.org/10.1073/pnas.0508200103

42. Muramatsu, T., Takemoto, C., Kim, Y.-T., Wang, H., Nishii, W., Terada, T., Shirouzu, M., Yokoyama, S., 2016. SARS-CoV 3CL protease cleaves its C-terminal autoprocessing site by novel subsite cooperativity. PNAS 113, 12997-13002. https://doi.org/10.1073/pnas.1601327113

43. Narayanan, K., Huang, C., Lokugamage, K., Kamitani, W., Ikegami, T., Tseng, C.-T.K., Makino, S., 2008. Severe Acute Respiratory Syndrome Coronavirus nsp1 Suppresses Host Gene Expression, Including That of Type I Interferon, in Infected Cells. Journal of Virology 82, 44714479. https://doi.org/10.1128/JVI.02472-07

44. Robinson, P., Garza, A., Moore, J., Eckols, T.K., Parti, S., Balaji, V., Vallejo, J., Tweardy, D.J., 2009. Substance $\mathrm{P}$ is required for the pathogenesis of EMCV infection in mice. Int J Clin Exp Med $2,76-86$.

45. Rota, P.A., Oberste, M.S., Monroe, S.S., Nix, W.A., Campagnoli, R., Icenogle, J.P., Peñaranda, S., Bankamp, B., Maher, K., Chen, M., Tong, S., Tamin, A., Lowe, L., Frace, M., DeRisi, J.L., Chen, Q., Wang, D., Erdman, D.D., Peret, T.C.T., Burns, C., Ksiazek, T.G., Rollin, P.E., Sanchez, A., Liffick, S., Holloway, B., Limor, J., McCaustland, K., Olsen-Rasmussen, M., Fouchier, R., Günther, S., Osterhaus, A.D.M.E., Drosten, C., Pallansch, M.A., Anderson, L.J., Bellini, W.J., 2003. Characterization of a Novel Coronavirus Associated with Severe Acute Respiratory Syndrome. Science 300, 1394-1399. https://doi.org/10.1126/science.1085952

46. Sakai, Y., Kawachi, K., Terada, Y., Omori, H., Matsuura, Y., Kamitani, W., 2017. Two-amino acids change in the nsp4 of SARS coronavirus abolishes viral replication. Virology 510, 165-174. https://doi.org/10.1016/j.virol.2017.07.019

47. Shi, X., Zhang, X., Chang, Y., Jiang, B., Deng, R., Wang, A., Zhang, G., 2016. Nonstructural protein 11 (nsp11) of porcine reproductive and respiratory syndrome virus (PRRSV) promotes PRRSV infection in MARC-145 cells. BMC Vet Res 12. https://doi.org/10.1186/s12917-0160717-5

48. Song, Z., Xu, Y., Bao, L., Zhang, L., Yu, P., Qu, Y., Zhu, H., Zhao, W., Han, Y., Qin, C., 2019. From SARS to MERS, Thrusting Coronaviruses into the Spotlight. Viruses 11, 59. https://doi.org/10.3390/v11010059

49. Su, S., Wong, G., Shi, W., Liu, J., Lai, A.C.K., Zhou, J., Liu, W., Bi, Y., Gao, G.F., 2016. Epidemiology, Genetic Recombination, and Pathogenesis of Coronaviruses. Trends Microbiol. 24, 490-502. https://doi.org/10.1016/j.tim.2016.03.003

50. Sutton, G., Fry, E., Carter, L., Sainsbury, S., Walter, T., Nettleship, J., Berrow, N., Owens, R., Gilbert, R., Davidson, A., Siddell, S., Poon, L.L.M., Diprose, J., Alderton, D., Walsh, M., Grimes, J.M., Stuart, D.I., 2004. The nsp9 replicase protein of SARS-coronavirus, structure and functional insights. Structure 12, 341-353. https://doi.org/10.1016/j.str.2004.01.016 
51. te Velthuis, A.J.W., Arnold, J.J., Cameron, C.E., van den Worm, S.H.E., Snijder, E.J., 2010. The RNA polymerase activity of SARS-coronavirus nsp12 is primer dependent. Nucleic Acids Res 38, 203-214. https://doi.org/10.1093/nar/gkp904

52. te Velthuis, A.J.W., van den Worm, S.H.E., Snijder, E.J., 2012. The SARS-coronavirus nsp7+nsp8 complex is a unique multimeric RNA polymerase capable of both de novo initiation and primer extension. Nucleic Acids Res 40, 1737-1747. https://doi.org/10.1093/nar/gkr893

53. Tsukuda, S., Watashi, K., Iwamoto, M., Suzuki, R., Aizaki, H., Okada, M., Sugiyama, M., Kojima, S., Tanaka, Y., Mizokami, M., Li, J., Tong, S., Wakita, T., 2015. Dysregulation of retinoic acid receptor diminishes hepatocyte permissiveness to hepatitis B virus infection through modulation of sodium taurocholate cotransporting polypeptide (NTCP) expression. J. Biol. Chem. 290, 56735684. https://doi.org/10.1074/jbc.M114.602540

54. Wan, Y., Shang, J., Graham, R., Baric, R.S., Li, F., 2020. Receptor Recognition by the Novel Coronavirus from Wuhan: an Analysis Based on Decade-Long Structural Studies of SARS Coronavirus. Journal of Virology 94. https://doi.org/10.1128/JVI.00127-20

55. Wang, L.-F., Shi, Z., Zhang, S., Field, H., Daszak, P., Eaton, B.T., 2006. Review of Bats and SARS. Emerg Infect Dis 12, 1834-1840. https://doi.org/10.3201/eid1212.060401

56. Woo, P.C.Y., Huang, Y., Lau, S.K.P., Yuen, K.-Y., 2010. Coronavirus Genomics and Bioinformatics Analysis. Viruses 2, 1804-1820. https://doi.org/10.3390/v2081803

57. Xia, B., Kang, X., 2011. Activation and maturation of SARS-CoV main protease. Protein Cell 2, 282-290. https://doi.org/10.1007/s13238-011-1034-1

58. Yang, H., Yang, M., Ding, Y., Liu, Y., Lou, Z., Zhou, Z., Sun, L., Mo, L., Ye, S., Pang, H., Gao, G.F., Anand, K., Bartlam, M., Hilgenfeld, R., Rao, Z., 2003. The crystal structures of severe acute respiratory syndrome virus main protease and its complex with an inhibitor. PNAS 100, 1319013195. https://doi.org/10.1073/pnas. 1835675100

59. Zhang, S., Zhong, N., Xue, F., Kang, X., Ren, X., Chen, J., Jin, C., Lou, Z., Xia, B., 2010. Threedimensional domain swapping as a mechanism to lock the active conformation in a super-active octamer of SARS-CoV main protease. Protein Cell 1, 371-383. https://doi.org/10.1007/s13238010-0044-8

60. Zhong, N., Zhang, S., Xue, F., Kang, X., Zou, P., Chen, J., Liang, C., Rao, Z., Jin, C., Lou, Z., Xia, B., 2009. C-terminal domain of SARS-CoV main protease can form a 3D domain-swapped dimer. Protein Sci 18, 839-844. https://doi.org/10.1002/pro.76

61. Zhong, N., Zhang, S., Zou, P., Chen, J., Kang, X., Li, Z., Liang, C., Jin, C., Xia, B., 2008. Without Its N-Finger, the Main Protease of Severe Acute Respiratory Syndrome Coronavirus Can Form a Novel Dimer through Its C-Terminal Domain. Journal of Virology 82, 4227-4234. https://doi.org/10.1128/JVI.02612-07

62. Zhong, N.S., Zheng, B.J., Li, Y.M., Poon, null, Xie, Z.H., Chan, K.H., Li, P.H., Tan, S.Y., Chang, Q., Xie, J.P., Liu, X.Q., Xu, J., Li, D.X., Yuen, K.Y., Peiris, null, Guan, Y., 2003. Epidemiology and cause of severe acute respiratory syndrome (SARS) in Guangdong, People's Republic of China, in February, 2003. Lancet 362, 1353-1358. https://doi.org/10.1016/s0140-6736(03)146302

63. Ziebuhr, J., Snijder, E.J., Gorbalenya, A.E., 2000. Virus-encoded proteinases and proteolytic processing in the Nidovirales. Journal of General Virology, 81, 853-879. https://doi.org/10.1099/0022-1317-81-4-853 
Tables -

Table 1 - Role of coronavirus non-structural proteins.

\begin{tabular}{|c|c|c|}
\hline nsp & Function & Reference \\
\hline nsp1 & $\begin{array}{l}\text { Translation inhibition and host mRNA } \\
\text { degradation }\end{array}$ & $\begin{array}{l}\text { Huang et al., 2011; } \\
\text { Narayanan et al., } 2008\end{array}$ \\
\hline nsp2 & $\begin{array}{l}\text { Host-and/or cell-specific roles with nsp1 and } \\
\text { nsp3, Disrupt host signaling }\end{array}$ & $\begin{array}{l}\text { Cornillez-Ty et al., 2009; } \\
\text { Graham et al., } 2006\end{array}$ \\
\hline nsp3 & Papain-like protease, cleaves nsP1, 2 and 3 & Lei et al., 2018 \\
\hline nsp4 & $\begin{array}{l}\text { Formation of double membrane vesicles (DMV), } \\
\text { interaction with nsp3 for virus propagation }\end{array}$ & $\begin{array}{l}\text { Beachboard et al., 2015; } \\
\text { Sakai et al., } 2017\end{array}$ \\
\hline nsp5 & 3CL proteinase, cleaves nsP4-16 & $\begin{array}{l}\text { Muramatsu et al., } 2016 \text {; } \\
\text { Ziebuhr et al., } 2000\end{array}$ \\
\hline nsp6 & $\begin{array}{l}\text { DMV formation with nsp3, } 4 \text { and 6, Limits } \\
\text { autophagosome size }\end{array}$ & $\begin{array}{l}\text { Angelini et al., 2013; } \\
\text { Cottam et al., } 2014\end{array}$ \\
\hline nsp7 & $\begin{array}{l}\text { Co-factor for nsp12, interaction with nsp } 8 \text { for de } \\
\text { novo intiation and primer extension }\end{array}$ & $\begin{array}{l}\text { Kirchdoerfer and Ward, } \\
\text { 2019; te Velthuis et al., } 2012\end{array}$ \\
\hline nsp8 & $\begin{array}{l}\text { Co-factor for nsp12, interacts with accessory } \\
\text { protein }\end{array}$ & $\begin{array}{l}\text { Kirchdoerfer and Ward, } \\
\text { 2019; Kumar et al., } 2007\end{array}$ \\
\hline nsp9 & $\begin{array}{l}\text { Single-stranded RNA binding protein, Interacts } \\
\text { with nsp8 }\end{array}$ & $\begin{array}{l}\text { Egloff et al., 2004; Sutton et } \\
\text { al., } 2004\end{array}$ \\
\hline nsp10 & Co-factor for nsp14 and nsp16 & Bouvet et al., 2014 \\
\hline nsp11 & Endoribonuclease in PRRSV* & Shi et al., 2016 \\
\hline nsp12 & $\begin{array}{l}\text { RNA dependent RNA polymerase activity with } \\
\text { nsp7 and nsp } 8\end{array}$ & $\begin{array}{l}\text { Ahn et al., 2012; } \\
\text { Kirchdoerfer and Ward, } \\
\text { 2019; te Velthuis et al., } \\
\text { 2010) }\end{array}$ \\
\hline nsp13 & Unwinding of duplex RNA, Helicase & $\begin{array}{l}\text { Adedeji et al., 2012; Hao et } \\
\text { al., } 2017\end{array}$ \\
\hline nsp14 & $\begin{array}{l}\text { 3'-5' exoribonuclease activity by interacting with } \\
\text { nsp10 }\end{array}$ & $\begin{array}{l}\text { Bouvet et al., 2012; } \\
\text { Minskaia et al., } 2006\end{array}$ \\
\hline nsp15 & $\begin{array}{l}\text { Endoribonuclease, Protect viral dsRNA from host } \\
\text { sensor detection }\end{array}$ & $\begin{array}{l}\text { Bhardwaj et al., 2004; Deng } \\
\text { et al., } 2017\end{array}$ \\
\hline nsp16 & 2'-O-Methyltranferase activity with nsp10 & $\begin{array}{l}\text { Chen et al., 2011; Decroly et } \\
\text { al., } 2011\end{array}$ \\
\hline
\end{tabular}


Table 2 - Representing different cleavage site between non-structural proteins in SARSCoV-2. (-- Represents cleavage site)

\begin{tabular}{|c|c|c|c|}
\hline Peptides & $\begin{array}{c}\text { Cleavage site } \\
\text { between non- } \\
\text { structural protein }\end{array}$ & Amino acid residues & $\begin{array}{c}\text { Binding Energy } \\
\text { (kcal/mol) }\end{array}$ \\
\hline Pep1 & nsp4 - nsp5 & AVLQ--SGFR & -7.5 \\
\hline Pep2 & nsp5 - nsp6 & VTFQ--SAVK & -6.5 \\
\hline Pep3 & nsp6-nsp7 & ATVQ--SKMS & -6.0 \\
\hline Pep4 & nsp7 - nsp8 & ATLQ--AIAS & -6.4 \\
\hline Pep5 & nsp8-nsp9 & VKLQ--NNEL & -6.3 \\
\hline Pep6 & nsp9 - nsp10 & VRLQ--AGNA & -6.8 \\
\hline Pep7 & nsp10 - nsp12 & PMLQ--SADA & -6.5 \\
\hline Pep8 & nsp12-nsp13 & TVLQ--AVGA & -7.0 \\
\hline Pep9 & nsp13 - nsp14 & ATLQ--AENV & -6.1 \\
\hline Pep10 & nsp14-nsp15 & TRLQ--SLEN & -6.1 \\
\hline Pep11 & nsp15 - nsp16 & PKLQ--SSQA & -6.2 \\
\hline
\end{tabular}


Table 3 - Representation of binding energies of top 10 screened potential antiviral compounds of LOPAC ${ }^{1280}$ library.

\begin{tabular}{|c|c|}
\hline Ligand & $\begin{array}{c}\text { Binding Energies } \\
\text { (kcal/mol) }\end{array}$ \\
\hline Etoposide & -10.23 \\
\hline BMS_195614 & -10.03 \\
\hline KT185 & -9.51 \\
\hline Idarubicin & -9.06 \\
\hline Win_62577 & -8.95 \\
\hline Eptifibatide_acetate & -8.80 \\
\hline KT203 & -8.60 \\
\hline SB_202190 & -8.60 \\
\hline GR_127935 & -8.60 \\
\hline GSK1210151A & -8.60 \\
\hline LP_12_hydrochloride_hydrate & -8.20 \\
\hline
\end{tabular}


Table 4 - The values of binding energy, inhibition constant ( $k i)$, H-bond interactions \& hydrophobic interactions obtained from docking of Etoposide, BMS_195614, KT185, Idarubicin, WIN_62577 into the catalytic site of $\mathrm{M}^{\text {pro }}$ (PDB ID: 6LU7) protein.

\begin{tabular}{|c|c|c|c|c|c|c|c|}
\hline \multirow[b]{2}{*}{ Compounds } & \multirow{2}{*}{$\begin{array}{c}\text { In silico } \\
\text { Inhibition } \\
\text { Constant } \\
\quad(k i)\end{array}$} & \multirow{2}{*}{$\begin{array}{c}\text { Binding } \\
\text { Energy } \\
\text { (kcal/mol) }\end{array}$} & \multicolumn{4}{|c|}{ H-bond } & \multirow{2}{*}{$\begin{array}{l}\text { Hydrophobic } \\
\text { Interactions }\end{array}$} \\
\hline & & & Residue No. & $\begin{array}{l}\text { No. of } \\
\text { Bonds }\end{array}$ & Molecules & $\begin{array}{c}\text { Bond } \\
\text { Length } \\
\left(\mathbf{A}^{0}\right)\end{array}$ & \\
\hline \multirow{6}{*}{ Etoposide } & \multirow{6}{*}{$31.86 \mathrm{nM}$} & \multirow{6}{*}{-10.23} & Leu141 & 1 & $\mathrm{O}-\mathrm{O} 12$ & 2.45 & \multirow{6}{*}{$\begin{array}{l}\text { His41, Phe140, } \\
\text { Asn142, Cys145, } \\
\text { His164, Met165, } \\
\text { Leu167, Pro168, } \\
\text { Asp187, Arg188, } \\
\text { Gln189, Thr190 }\end{array}$} \\
\hline & & & Gly143 & 1 & N-O13 & 3.13 & \\
\hline & & & \multirow{2}{*}{ Ser144 } & \multirow[t]{2}{*}{2} & OG-O12 & & \\
\hline & & & & & $\mathrm{N}-\mathrm{O} 12$ & 2.82 & \\
\hline & & & His 163 & 1 & $\begin{array}{l}\text { NE2- } \\
\text { O11 }\end{array}$ & 2.78 & \\
\hline & & & Glu166 & 1 & $\mathrm{O}-\mathrm{O} 10$ & 2.77 & \\
\hline BMS_195614 & $44.5 \mathrm{nM}$ & -10.03 & & & & & $\begin{array}{c}\text { His41, Phe140, } \\
\text { Leu141, Asn142, } \\
\text { His163, His164, } \\
\text { Met165, Glu166, } \\
\text { Leu167, Pro168, } \\
\text { Asp187, Arg188, } \\
\text { Gln189 }\end{array}$ \\
\hline KT185 & $\begin{array}{c}106.50 \\
\mathrm{nM}\end{array}$ & -9.51 & $\operatorname{Arg} 188$ & 1 & $\mathrm{O}-\mathrm{N} 4$ & 3.11 & $\begin{array}{c}\text { His41, Cys145, } \\
\text { His164, Met165, } \\
\text { Glu166, Leu167, } \\
\text { Pro168, Gly170, } \\
\text { Asp187, Gln189, } \\
\text { Thr190 }\end{array}$ \\
\hline \multirow{3}{*}{ Idarubicin } & \multirow{3}{*}{$\begin{array}{c}229.43 \\
\mathrm{nM}\end{array}$} & \multirow{3}{*}{-9.06} & Asn142 & 1 & OD1-O3 & 2.75 & \multirow{3}{*}{$\begin{array}{c}\text { His41, Tyr54, } \\
\text { Phe140, Leu141, } \\
\text { His164, Met165, } \\
\text { Glu166, Leu167, } \\
\text { Asp187, Arg188, } \\
\text { Gln189 }\end{array}$} \\
\hline & & & Cys 145 & 1 & SG-O8 & 3.33 & \\
\hline & & & Pro168 & 1 & $\mathrm{O}-\mathrm{O} 7$ & 3.31 & \\
\hline
\end{tabular}




\begin{tabular}{|c|c|c|c|c|c|c|c|}
\hline WIN_62577 & $\begin{array}{c}273.66 \\
\mathrm{nM}\end{array}$ & -8.95 & Glu166 & 1 & OE1-N3 & 2.99 & $\begin{array}{l}\text { Thr25, Thr6, } \\
\text { Leu27, His41, } \\
\text { Met49, Leu141, } \\
\text { Asn142, Gly143, } \\
\text { Cys145, His164, } \\
\text { Met165, Leu167, } \\
\text { Pro168, Gln189 }\end{array}$ \\
\hline
\end{tabular}


Table 5 - Identified potential drug molecules against $\mathrm{M}^{\text {pro }}$ of SARS-CoV-2 and their role on RNA viruses.

\begin{tabular}{|c|c|c|c|}
\hline S.No. & $\begin{array}{l}\text { Identified } \\
\text { drugs }\end{array}$ & $\begin{array}{l}\text { Reported function } \\
\text { of drug }\end{array}$ & Role on RNA viruses \\
\hline 1 & $\begin{array}{l}\text { KT185 } \\
\text { KT203 }\end{array}$ & Anti-inflammatory & $\begin{array}{l}\text { - Inhibitor of ABHD6 receptor. } \\
\text { - Decreases macrophage activation and } \\
\text { exerts anti-inflammatory effect on lungs } \\
\text { (Bottemanne et al., 2019; Hsu et al., } \\
\text { 2013) }\end{array}$ \\
\hline 2 & $\begin{array}{c}\text { GR127935 } \\
\text { hydrochloride } \\
\text { hydrate }\end{array}$ & $\begin{array}{l}\text { Controls } \\
\text { vasoconstriction }\end{array}$ & $\begin{array}{l}\text { - Antagonist of 5-HT1B/1D serotonin } \\
\text { receptor. } \\
\text { - Serotonin antagonists are potent entry } \\
\text { inhibitors of Ebola and Marburg virus } \\
\text { (Cheng et al., 2015) }\end{array}$ \\
\hline 3 & $\begin{array}{l}\text { Eptifibatide } \\
\text { acetate }\end{array}$ & $\begin{array}{l}\text { Lungs injury and } \\
\text { inflammation }\end{array}$ & $\begin{array}{l}\text { - Inhibitor of glycoprotein IIb/IIIa receptor } \\
\text { responsible for platelet aggregation } \\
\text { - Protects lungs from severe injury and } \\
\text { inflammations induced by Influenza virus } \\
\text { (Lê et al., 2015) }\end{array}$ \\
\hline 4 & Etoposide & Anti-cancer drug & $\begin{array}{l}\text { - Blocks cell cycle in } \mathrm{S} \text { or } \mathrm{G} 2 \text { phase, } \\
\text { inhibits } \mathrm{Mdm} 2 \text { synthesis }\end{array}$ \\
\hline 5 & WIN_62577 & $\begin{array}{l}\text { Anti-inflammatory } \\
\text { drug }\end{array}$ & $\begin{array}{l}\text { - Tachykinin receptor (Substance P } \\
\text { receptor) antagonist } \\
\text { - Substance P is required for EMCV } \\
\text { pathogenesis (Robinson et al., 2009) } \\
\text { - Reduces bronchial smooth muscle } \\
\text { constriction infected with RSV (Bost, } \\
\text { 2004) }\end{array}$ \\
\hline 6 & BMS_195614 & Anti-cancer drug & $\begin{array}{l}\text { - Inhibitor of Retinoic acid receptor } \\
\text { - Inhibits Hepatitis B virus infection by } \\
\text { decreasing hepatocyte permissiveness, } \\
\text { through modulation of sodium } \\
\text { taurocholate cotransporting polypeptide } \\
\text { (NTCP) expression (Tsukuda et al., 2015) }\end{array}$ \\
\hline 7 & $\begin{array}{l}\text { GSK1210151A } \\
\text { (I-BET151) }\end{array}$ & $\begin{array}{l}\text { Bromodomain } \\
\text { inhibitor }\end{array}$ & $\begin{array}{l}\text { - Transcriptional repression of } \mathrm{MYC} \\
\text { (Chaidos et al., 2014) } \\
\text { - MYC expression increased upon HCV } \\
\text { induce } \beta \text {-catenin activation (Higgs et al., } \\
\text { 2013) }\end{array}$ \\
\hline 8 & $\begin{array}{l}\text { LP-12-HCl- } \\
\text { hydrate }\end{array}$ & $\begin{array}{l}\text { Serotonin receptor } \\
\text { agonist }\end{array}$ & $\begin{array}{l}\text { - Agonist 5-Nonyloxytryptamine affects at } \\
\text { Reovirus entry step (Mainou et al., 2015) }\end{array}$ \\
\hline
\end{tabular}




\begin{tabular}{|c|c|c|c|}
\hline 9 & SB202190 & $\begin{array}{l}\text { p38 activation } \\
\text { inhibitor }\end{array}$ & $\begin{array}{l}\text { - Damages Zaire ebolavirus entry and } \\
\text { reduce cytokine induction (Johnson et al., } \\
\text { 2014) } \\
\text { - Disrupts primary and secondary Host } \\
\text { Gene Responses of Influenza virus } \\
\text { (Börgeling et al., 2014) }\end{array}$ \\
\hline
\end{tabular}




\section{Figure Legends -}

Fig. 1 - Schematic representation of SARS CoV-2 non-structural genes with boxes depicting their approximate protein size. Triangles are showing protease cleavage site of papain-like protease (black) and 3CL-protease (white).

Fig. 2 - Multiple Sequence Alignment (MSA) of binding pocket of $\mathrm{M}^{\text {pro }}$ of SARS-CoV-2, SARS-CoV and MERS-CoV showing consensus amino acids (His41, Cys145).

Fig. 3 - MSA of cleavage site between different non-structural proteins. (a) Pep1: between nsp4 - nsp5, (b) Pep2: between nsp5 - nsp6, (c) Pep3: between nsp6- nsp7, (d) Pep4: between nsp7 - nsp8, (e) Pep5: between nsp8 - nsp9, (f) Pep6: between nsp9 - nsp10, (g) Pep7: between nsp10 - nsp12, (h) Pep8: between nsp12 - nsp13, (i) Pep9: between nsp13 - nsp14, (j) Pep10: between nsp14 - nsp15 and (k) Pep11: between nsp15 - nsp16. Red color shows the conserved sequence.

Fig. 4 - Molecular docking interactions and orientations of top 10 screened ligands (top 5 compounds shown in green and remaining are in red) from LOPAC library and peptide (Pep1) shown in black color with binding pocket of $\mathrm{M}^{\text {pro }}$ (a) Ribbon diagram and (b) Surface structure. Yellow color sticks represents interacting residues of $\mathrm{M}^{\text {pro }}$.

Fig. 5 - Molecular docking interactions and orientations of peptide (Pep1) with binding pocket of Mpro (a) Ribbon diagram and (b) Surface structure. Peptide is in black color, red represents catalytic dyad ( His41 and Cys145) of Mpro and yellow color sticks represents interacting residues(Phe140, Asn142, Gly143, Ser144, Tyr161, His163, Glu166, His172 ) of Mpro.

Fig. 6 - Molecular docking interactions and orientations of top-hit screened ligands from LOPAC library with binding pocket of $\mathrm{M}^{\mathrm{pro}}$. (a) Etoposide, (b) BMS_195614, (c) KT 185, (d) Idarubicin and (e) WIN_62577. Cyan ribbons corresponds to residues of $\mathrm{M}^{\mathrm{pro}}$, simple presentation of ligand (red-green) with $60 \%$ transparency, yellow stick model represents hydrogen bonds and light blue stick model corresponds to hydrophobic interactions.

Fig. 7 - In-silico molecular docking surface structure of top-hit screened ligands from LOPAC library with binding pocket of $\mathrm{M}^{\text {pro }}$. (a) Etoposide, (b) BMS_195614, (c) KT 185, (d) Idarubicin and (e) WIN_62577. $\mathrm{M}^{\text {pro }}$ residues are shown in marine with $20 \%$ transparency, hydrophobic residues are shown in green, hydrogen bonds are in red color and ligand residues are shown in orange with $20 \%$ transparency.

Fig. 8 - Schematic representation of interactions made by screened drug molecules with binding pocket of $\mathrm{M}^{\text {pro }}$ of SARS-CoV-2 upon analysis using Ligplot. (a) Etoposide, (b) BMS_195614, (c) KT 185, (d) Idarubicin and (e) WIN_62577. Ligands are colored and represented in purple color, hydrogen bonds are displayed in green dotted lines, red stellations represents hydrophobic interactions and residues of proteins are shown in brown color. 